Provided for non-commercial research and education use. Not for reproduction, distribution or commercial use.

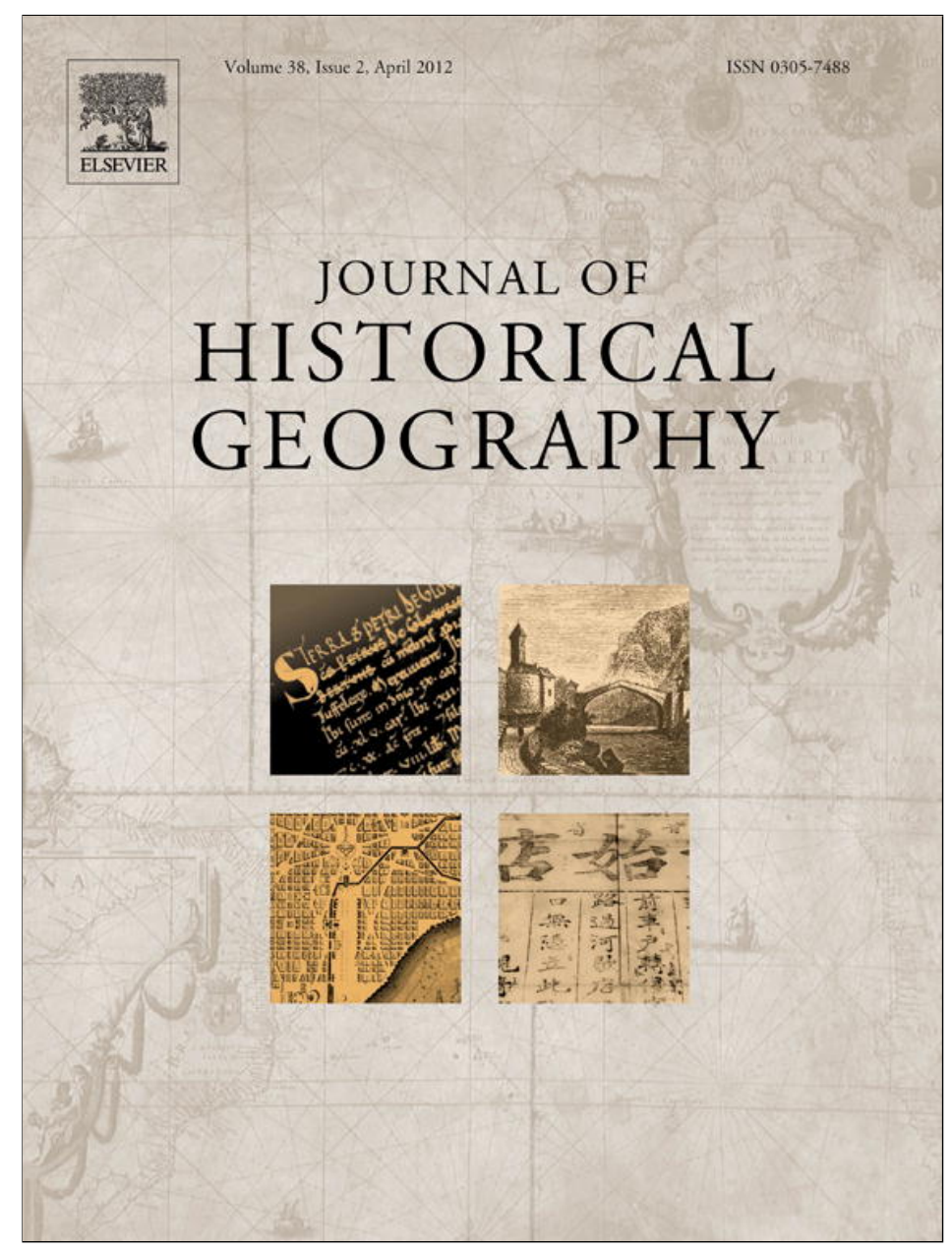

This article appeared in a journal published by Elsevier. The attached copy is furnished to the author for internal non-commercial research and education use, including for instruction at the authors institution and sharing with colleagues.

Other uses, including reproduction and distribution, or selling or licensing copies, or posting to personal, institutional or third party websites are prohibited.

In most cases authors are permitted to post their version of the article (e.g. in Word or Tex form) to their personal website or institutional repository. Authors requiring further information regarding Elsevier's archiving and manuscript policies are encouraged to visit:

http://www.elsevier.com/copyright 


\title{
Regeneration and mobility: the spatial dynamics of industries in wartime Shanghai
}

\author{
Christian Henriot ${ }^{\mathrm{a}, \mathrm{b}, *}$ \\ ${ }^{a}$ Institut d'Asie Orientale, France \\ ${ }^{\mathrm{b}}$ University of Lyon, Institut Universitaire de France, France
}

\begin{abstract}
During the three-month long Sino-Japanese hostilities in the summer of 1937, Shanghai industries suffered the heaviest loss ever sustained during any previous military conflict in the city. Yet as has been shown in a previous study, local industries seem to have recovered fairly quickly. All statistics point to a return to pre-war levels of production in most sectors by the end of 1938 in some cases and during 1939 for most industrial branches. The purpose of this paper is to try to highlight the spatial dynamics at work in this recovery process. It relies not just on original sources, but on the unique capabilities GIS offers in processing large amounts of historical data and exploring connected issues in land use, demography, and urban life. The paper argues that Shanghai industries went through a thorough phase of relocation and migration within the city, but also of inbound migration from the surrounding regions. This study is based on a particular set of documents produced by the Shanghai Municipal Council, the largely independent body that administered the International Settlement. In this study, therefore, I shall argue that what happened in the territory of the International Settlement mirrored what happened next door and possibly in other parts of the Chinese-administered/Japanese-occupied areas. Beyond the issue of industrial movement, this paper also examines connected issues in land use, demography, and urban life.
\end{abstract}

(c) 2011 Elsevier Ltd. All rights reserved.

Keywords: Industry; War; Shanghai; Urban space; Land use

During the three-month long Sino-Japanese hostilities in the summer of 1937, Shanghai industries suffered the heaviest loss ever sustained during any previous military conflict in the city. Five years earlier, a month-long battle had already laid waste large tracks of urban neighborhoods, but bombing and fires had taken their toll only on a single Chinese-administered area, Zhabei. In 1937, this area was not only razed to the ground, Hongkou and Yangshupu - the latter a major industrial base - in the International Settlement also suffered serious damage. ${ }^{1}$ The duration of the conflict and its intensity far surpassed the 1932 'Sino-Japanese incident'. Yet as has been shown in a previous study, local industries seem to have recovered fairly quickly. All statistics point to a return to pre-war levels of production in most sectors by the end of 1938 in some cases and during 1939 for most industrial branches. ${ }^{2}$ The purpose of this paper is to try to highlight the spatial dynamics at work in this recovery process. It relies not just on original sources, but on the unique capabilities GIS offers in processing large amounts of historical data and exploring connected issues in land use, demography, and urban life. The paper argues that Shanghai industries went through a thorough phase of relocation and migration within the city, but also of inbound migration from the surrounding regions.

Shanghai presented a unique territorial configuration due to the existence of several autonomous administrative jurisdictions within the city (Fig. 1). Originally made up of the walled city and its southern suburbs - a harbor and trading area - Shanghai saw the institution of foreign settlements (British, French, and American) after the Opium wars, ruled by foreigners under the privilege of extraterritoriality. Along with the rise of the city as a major trade center, new neighborhoods (Zhabei) also emerged to the north of the foreign establishments while further spatial expansion into the countryside by the latter literally swallowed up the myriads of

\footnotetext{
* University of Lyon, Institut Universitaire de France, France.

E-mail addresses: christian.r.henriot@gmail.com, christian.henriot@univ-lyon2.fr

1 In this paper, I shall use pinyin when referring to designated place names in the city, like 'Hongkou', 'Yangshupu' or 'Zhabei' that represented whole urban areas, yet with undefined limits. However, I shall use the names as labelled by the Shanghai Municipal Council of the International Settlement when referring to its police districts, both for reasons of historical consistency and because the spaces so designated did not overlap with their name in Chinese, e.g. Yangtszepoo (Yangshupu) was only one district within the large area known as 'Yangshupu' in Chinese; Hongkou was a much larger area than the Hongkew (Hongkou) police district.

${ }^{2}$ C. Henriot, Shanghai industries under Japanese occupation: bombs, boom and bust (1937-1945), in: C. Henriot and W.-H. Yeh (Eds), In the Shadow of the Rising Sun: Shanghai under Japanese Occupation, Cambridge/New York, 2004, 17-45.
} 


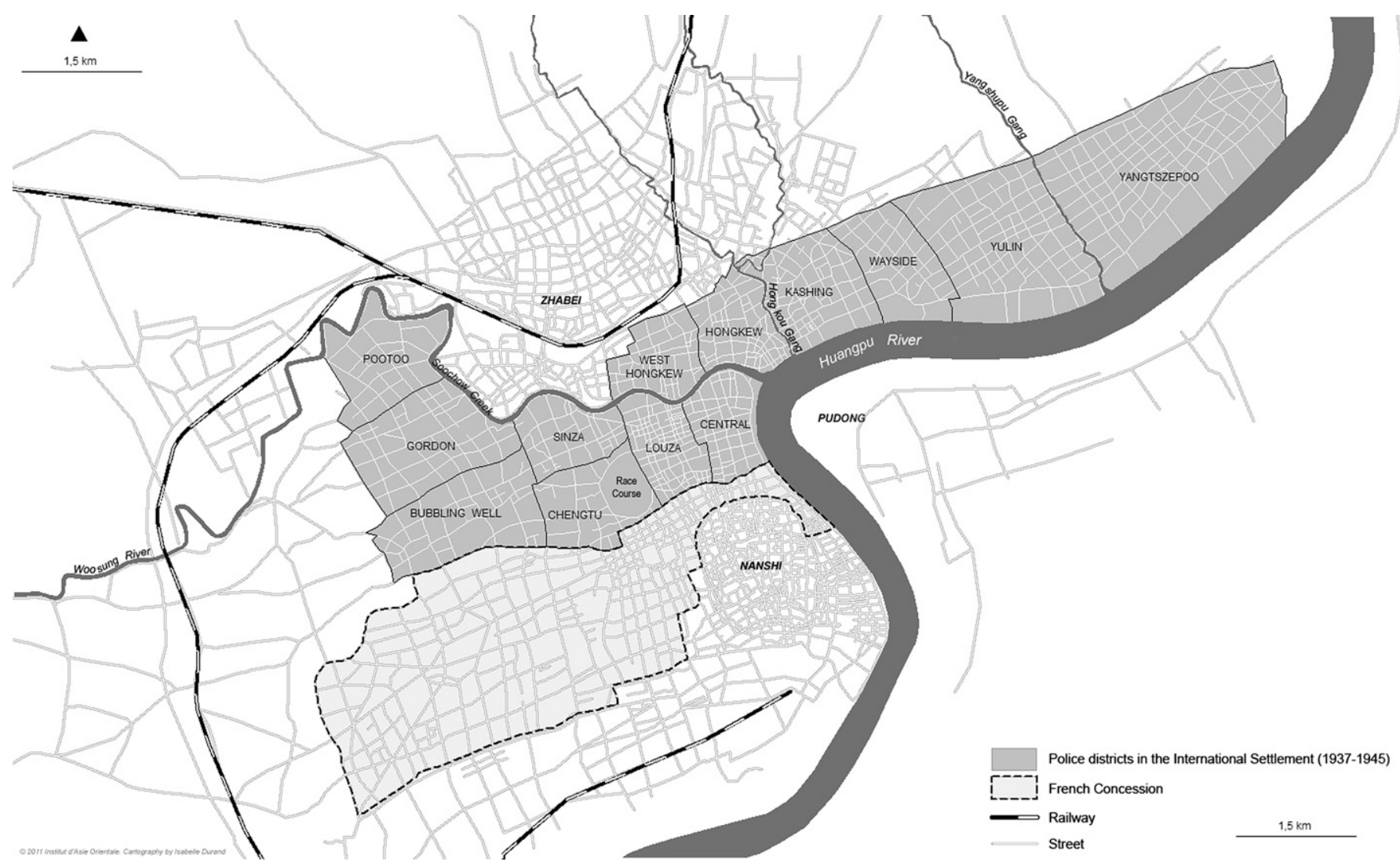

Fig. 1. Shanghai and police districts in the International Settlement.

villages and fields all around. By the 1930s, the city was made up of two central blocks - the French Concession and the International Settlement - bordered by two Chinese-administered areas to the north (Zhabei) and the south (Nanshi, former walled city). With regard to the development of industries, the general pattern was one of unequal distribution and functional difference between the various districts. With the French Concession remaining mostly a commercial and residential district and Nanshi retaining its central role as a commercial district (shops, craftsmen), industrial ventures concentrated mostly in the International Settlement and Zhabei.

At the end of fighting in November 1937, fighting moved away from Shanghai in a westward direction. The Japanese army occupied all the former Chinese-administered districts (Chinese municipality). Around one million people had left these areas to seek refuge in the foreign-protected settlements. While a part of this population returned to the Japanese occupied districts in the early part of 1938 and the following years, these areas remained under the control and power of the Japanese, with a constant risk of abuse at all levels, individual but also economic. The unique political and military configuration - an occupied city with its central areas beyond the reach of the occupant and continuously linked to the outside world by river and sea by virtue of their status of extraterritoriality - remained in place until December 1941 when the Japanese took over the International Settlement and put an end to the protection the population enjoyed, in particular Chinese entrepreneurs. In view of the arbitrary and often exploitative measures implemented both by the collaborationist government and the Japanese forces through tax, confiscation or occupation, Chinese factory owners had all the reasons to move their machines and workforce to the International Settlement before $1941 .^{3}$

In 1939-1940, the China Weekly Review, a major and wellinformed independent publication, published a series of papers on Chinese industry. It presented a gloomy picture of Shanghai factories based on figures that did reflect the heavy losses suffered by Chinese companies. Its overall assessment, however, overlooked the fact that gross industrial production was already back to pre-war level, even if some major sectors were still below their pre-war record. What it also missed was the fact that many workshops had escaped destruction not because bombs or fires went around them, but because their equipment had been removed beforehand. When the CWR reported on figures of plants and production, its argument was focused on production, not on where production was taking place, except indirectly. It referred to closed down or confiscated plants by the Japanese army in the Chinese municipality. ${ }^{4}$ Yet it failed to mention that those in operation had found a safer haven in the foreign settlements.

If statistical indexes establish with little doubt the formidable capacity of Shanghai industries to come back to life from their ashes, they actually fall short of providing clues about the actual process and its consequences on urban space. Factories are first of all physical entities made up of buildings and inventory. If both are damaged or destroyed, new capital is needed to rebuild premises and purchase new machinery. Factories are also human communities. In Shanghai they ranged from a few individuals for the small

\footnotetext{
3 P. Coble, Chinese Capitalists in Japan's New Order: The Occupied Lower Yangzi, 1937-1945, Berkeley, 2004, 43-44.

${ }^{4}$ China Weekly Review, 15 July 1939, 212.
} 
workshops to thousands of workers for the large textile mills. As we shall see, our data include all the factories with staff above 10 workers. For any factory to resume production after battle time, it had to find a suitable location with premises and a workforce. The military conflict that raged for three months in and around Shanghai caused the workers to scatter all over or even to leave the city. Yet the power of attraction of the city soon resumed its power to siphon off manual workers from the countryside.

The rebirth of Shanghai industries in 1938-1940, therefore, raises a whole set of questions. If some areas were thoroughly razed to the ground, including the destruction of basic infrastructures (water, electricity, roads, etc.), how could workshops and factories be reestablished? If the whole area previously administered by the Shanghai Municipal Government came under Japanese occupation, could this play in favor of or against reestablishing new plants in these areas in terms of risk assessment? In other words, where did the recovery take place? Given the short time span within which workshops and factories resumed production, are there alternative explanations to full or partial destruction made up through the purchase of new equipment, especially for the vast majority of smaller ventures? If war reshaped the spatial configuration of local industries, what were the driving factors and the consequences of this new territorial arrangement? In particular, what were the economic and social dynamics at work in the process of industrial reconstruction?

This study is based on a particular set of documents produced by the Shanghai Municipal Council, the largely independent body that administered the International Settlement. While the set of documents we used may present an apparent bias, I shall establish that the remarkable data produced by the Shanghai Municipal Council actually the Shanghai Municipal Police - are the best documentary trail of the dramatic spatial transformation of Shanghai industries during wartime. It was not a deliberate choice to focus on these materials. It was a choice dictated by the sources. Ideally, I would have liked to use similar data sets from the Chinese Municipality (Shanghai shi zhengfu), especially for the Zhabei and Nanshi districts. From my previous work on this institution, we know that they certainly had registered all the industrial premises on their territory. The biggest stumbling block for such an exploration, however, is that all the municipal archives for the 1927-1937 have disappeared. ${ }^{5}$ Moreover, in the early years after the fighting, there was hardly any capable and autonomous municipal administration to speak of in the Chinese municipality. ${ }^{6}$ We may assume that this past is irremediably irretrievable. In this study, therefore, I shall argue that what happened in the territory of the International Settlement was the inverse mirror of what happened next door and possibly in other parts of the Chinese-administered/Japanese-occupied areas.

The data I use are the annual industrial surveys of the Shanghai Municipal Police. Every year in July, the SMP surveyed each factory and workshop with more than 10 workers. I do not know when this policy was introduced. From the currently available records at the Shanghai Municipal Archives, an initial survey was made by 1930 as part of a campaign for 'lime washing and cleansing' of all 'tenement workshops' in the International Settlement. ${ }^{7}$ It was carried out in each police sub-districts whose officers produced detailed lists accompanied with a map of their respective district. Each industrial venture was precisely located on these maps. The SMP simply established a list of factories with their name in Chinese and English, address, number of workers, and nationality. Unfortunately, the current condition of the microfilmed documents makes it extremely difficult to use this first set of materials. The following year, the SMP carried out a new survey that basically integrated the methodology and all the elements of information that would appear in the subsequent surveys. The model was in place. The earliest such survey found after the 1931 campaign is 1934 . The SMA catalog currently holds the series up to $1940 . .^{8}$ Only the year 1937 is missing. While 1937 was an exceptional year, with war starting in North China in early July, there is no real explanation as to the absence of survey in that year as it used to be conducted in July. After the takeover of the International Settlement by the Japanese Army in December 1941, surveys must have been suspended with the disruption in the work of the Shanghai Municipal Council. Yet the July 1941 survey could have been carried out.

While the present study is based on the analysis of this set of surveys, the documents themselves were not new to me. I collected the 1936, 1938, and 1939 surveys as early as 1996 as part of my work on wartime Shanghai. Yet apart from being difficult to process, I could not see the relevance of using them as I could get alternative data on workforce and nationality in a more synthetic form from other sources. This paper takes another approach to these surveys as the data that lies therein can now be processed and introduced into a GIS. With the Virtual Shanghai project, I have established a GIS platform that contains multiple layers of data, including a vectorial layer of Shanghai street grid for the republican period. ${ }^{9}$ All along, we have been adding geocoded street numbers on each street in the two foreign settlements. This is far from complete, but each survey gives us an opportunity to add more. ${ }^{10}$ The major source on which we rely for street numbers is the extraordinary street atlas produced in 1939-1940 that matches exactly the time period of the industrial surveys. ${ }^{11}$ This atlas is also fully available on line as a georectified document on the Virtual Shanghai platform (see Live Maps menu). This paper is part of a broader study of Shanghai industries in situations of social, political or economic upheaval and will include a similar approach of the civil war period (1945-1949) using the same methodology. Its larger context is a collective project on 'cities in turmoil' that examines various processes of social and economic transformation in Shanghai, Beijing, and Hankou before 1949 through the application of H-GIS.

The set of surveys that I processed contained 3363 individual factories. They were turned into tabular data and entered into the Virtual Shanghai GIS server. This allowed me to trace their trajectory (appearance, disappearance, location) through a double entry: name and address (in addition the industrial sector usually helped eliminate possible confusion resulting from same-named plants), even if various issues arose in the actual identification process. ${ }^{12}$ The 1936 survey provided the state of industries in the International Settlement before the war. Of course, this was one full year before the hostilities broke out. In-between, factories may have

\footnotetext{
${ }^{5}$ C. Henriot, Shanghai 1927-1937: Municipal Power, Locality, and Modernization, Berkeley, 1993.

6 T. Brook, The great way government of Shanghai, in: Henriot and Yeh, In the shadow of the Rising Sun, 157-186

7 File U1-14-1327, Shanghai Municipal Archives [thereafter SMA].

8 Files U1-16-2102 [1934], U1-16-2103 [1935], U1-16-2104 [1936], U1-14-598 [1938], U1-16-2105 [1939], U1-14-596 [1940], SMA.

9 Virtual Shanghai Project: http://virtualshanghai.net.

10 On the methodological aspects, see C. Henriot and I. Durand, The Shanghai industrial surveys: a GIS-based analysis, Annals of GIS (forthcoming). doi:http://dx.doi.org/10. 1080/19475683.2011.647080.

11 Shanghai shi hanghao lutu lu 上海市行號路圖錄 (Shanghai Street Directory), Shanghai, 1939-1940, Vol. 2 The source atlas was made up of hundreds of individual maps

that we georectified and stitched together so as to create maps that could be used in ArcGIS.

12 These issues are addressed in Henriot and Durand, The Shanghai industrial surveys (note 10).
} 


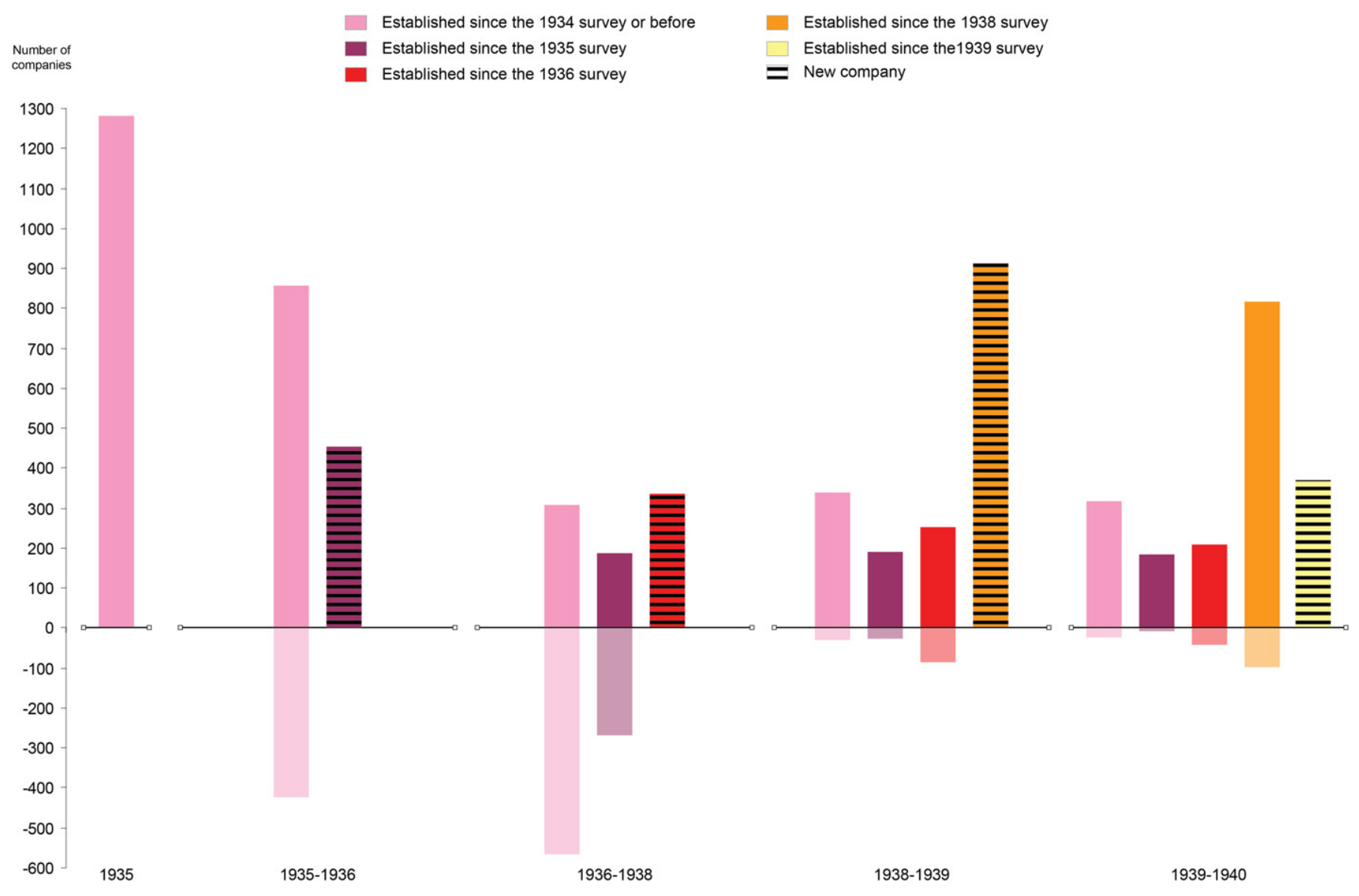

Fig. 2. Turnover of industrial companies in Shanghai, 1935-1940.

shut down while new plants may have been started. Yet there is no reason to believe that a drastic change could have occurred, as there were no particular circumstances that could have given a serious blow or upshot to local industries. Basically, the Chinese economy was on an upward curve following the currency reform and the slight inflationary policy of the national government. I actually used the 1935 survey to examine how much turnover there was. There is no doubt that Shanghai was a competitive economy, with numerous failures. Yet apart from affecting mostly certain sectors like silk, this was compensated by the emergence of new factories. About one third of the 1935 survey did not make it into the next survey, but conversely $35 \%$ of the 1936 plants did not exist the previous year (see Fig. 2). There is nothing we can do with the missing data for 1937 at this stage. The subsequent surveys for the 1938-1940 period provided a full photograph of the industrial landscape for each year.

\section{Industries in pre-war Shanghai}

In pre-war Shanghai, industries were distributed all over the city, even if due to space constraints, local regulations and transportation facilities, some areas had become genuine industrial districts while other hosted only small-scale workshops or severely restricted industrial activity on their territory. ${ }^{13}$ In Nanshi, the former walled city, the density of population and housing premises, not to mention the narrow lanes, limited the possibility of significant industrial development. At best, workshops and plants could settle in the southern suburbs, but Nanshi remained mostly an area dominated by trade and small craftsmen workshops. ${ }^{14}$ In the French Concession, industry was strictly regulated. All the establishments that could cause noise and pollution ('établissements classés' in administrative jargon) were relegated to an area bordering Chinese-administered territory along the Zikawei Road. The French Concession preserved its character as a residential and commercial area. Industries, therefore, thrived mostly in the districts north of Soochow Creek in the International Settlement and in Zhabei. The two dominant sectors in the settlement were Yangshupu, in the eastern district, as well as the riverbank in the Western district. This is where the largest plants, especially cotton mills, were to be found. Yet many smaller workshops could be found throughout the settlement. Zhabei was a 'new' area that had developed after 1900. It soon became home to hundreds of mostly small- and middle-sized factories and workshops. ${ }^{15}$ Compared to the area south of Soochow Creek, both Zhabei and Yangshupu offered large tracks of unbuilt cheap land. The distribution of Shanghai industries took the shape of Napoleon's famous hat, with

\footnotetext{
13 This section strongly disagrees with Park Coble's view that the territory of the foreign concessions held little industry before the war. Coble, Chinese Capitalists 20.

$14 \mathrm{X}$. Liu, Jindai shanghai shiliupu yanjiu (A study of Shiliupu in modern Shanghai), East China Normal University, M.A. thesis, 2005.

15 On the development of Zhabei, see L. Cai, Jindai zhabei de subeiren (1900-1949) (Subei people in Zhabei in the modern era, 1900-1949), East China Normal University, M.A. thesis, 2006 and the splendid study by X. Zhang, Jindai shanghai zhabei jumin shehui shenghuo (The social life of Zhabei residents in modern Shanghai) Shanghai, 2009.
} 


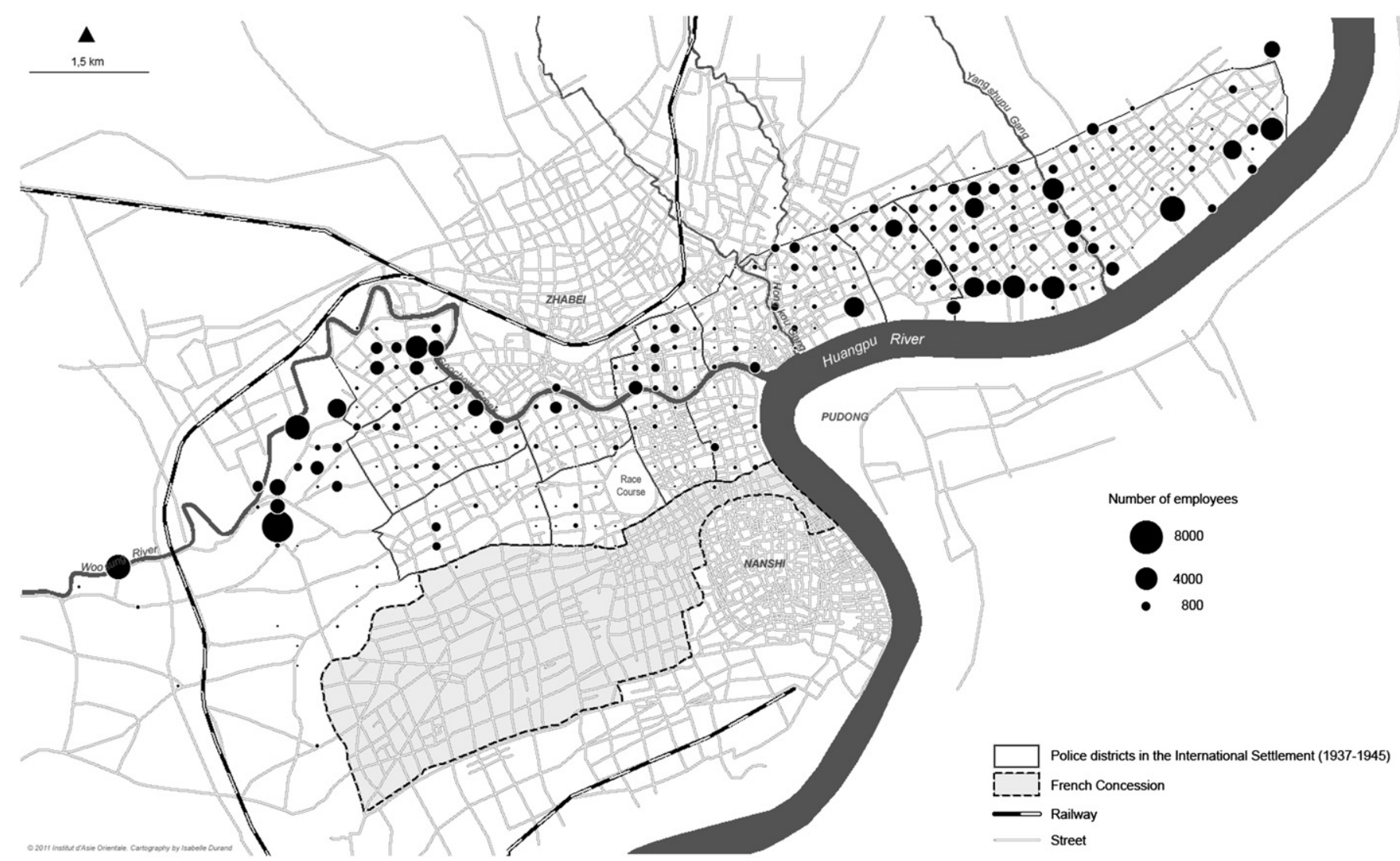

Fig. 3a. Factories and workforce, 1936.

Zhabei and its thousands of small workshops forming the top flanked by the two concentrations of heavy weight factories in the Eastern and Western districts of the International Settlement. ${ }^{16}$

If we examine the structure of industry in the International Settlement before the war (Fig. 3), it becomes clear that plants were concentrated in the eastern-most half of the Yangshupu area and the northern-most corner of the Western district. Small- and middle-size factories also colonized the Western border of the settlement and beyond (Extra-settlement road area, thereafter ESRA), while smaller workshops were scattered all over, including the Central district. Hongkew (a Japanese-populated area) was clearly much less industrialized, whereas West Hongkew - adjacent to Zhabei - was home to a multitude of workshops. The residential area west of the racecourse was mostly spared the presence of industrial premises. Actually, in terms of concentration of workforce in proportion of space (Grid map), there was an almost continuous ribbon all along the two riverbanks, from East to West.

In terms of factories, the two main industrial areas (Yangshupu area and the Pootoo-Gordon districts) hosted about 36.5 percent of the total ( 40 percent with ESRA), but each sector represented 55\% and $18 \%$ of the total workforce respectively (18 percent in ESRA). The central and northern districts accounted for $59 \%$ of all establishments, but only 3 and 6 percent of the workforce respectively. The employment structure was seriously skewed by the existence of very large textile mills. Even if the Western and Eastern districts showed overwhelming rates for almost all industrial sectors, textile represented 72 per cent and 54 percent of the total number of workers in each area respectively. If we include the Extra-settlement road area, the share for western Shanghai came to 77 percent. ${ }^{17}$ Textile and printing were major employers (20-22 per cent each) in the Northern district, while printing (65 per cent) clearly predominated in the Central district. Most of the tobacco factories (90 percent) were located in the Eastern district.

The 1936 SMP survey revealed the presence of 1311 factories with a total workforce numbering 171,685 workers. The average workforce per factory stood at 132 workers. The survey, therefore, missed a large number of smaller workshops that were discounted as craftsmen's workshops. ${ }^{18}$ The share of Chinese-run companies ran at a high 87 percent, while their share of the workforce only reached 58 percent. British and American companies employed 29,053 workers in only 7 percent of all plants, with the Japanese factories clearly ahead with 41,389 workers in their 63 plants

\footnotetext{
16 There were some elements of similarity with Tokyo in Shanghai's industrial development, except for the lack of previous dense crafts production in the city proper. P. Waley, Distinctive patterns of industrial urbanization in modern Tokyo, c. 1880-1930, Journal of Historical Geography 35 (2009) 406-407.

17 The Extra-settlement road area (ESRA) was an unofficial extension of the International Settlement through the building of roads and acquisition of land. It was not recognized as a legal part of the settlement by the Chinese authorities. The ambiguous status of this area was the source of recurrent tensions and conflicts.

18 The next full survey of Shanghai industries was compiled in 1947 for the entire municipality. It included all the factories and workshop irrespective of their workforce. A preliminary study shows both a heavy concentration in the former International Settlement. Yet factories dotted all areas. It also shows again an astonishing take off from the late wartime situation. Shanghai zhizao changshang gailan (A Compendium of Shanghai Manufacturing Firms), Shanghai, 1947.
} 
1938

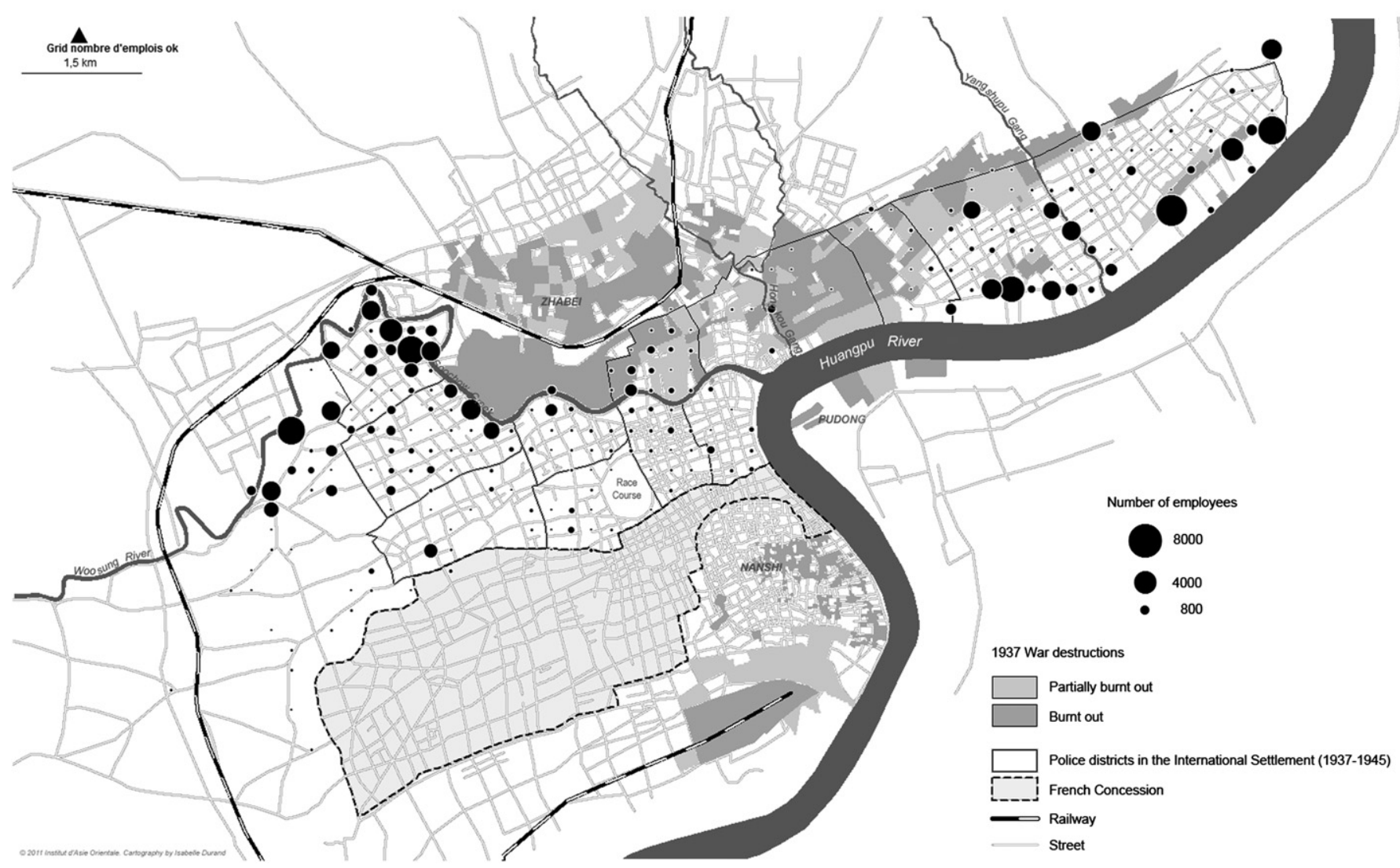

Fig. 3b. Factories and workforce, 1938.

(5 percent). The forte of Chinese factories was tobacco, printing, pharmaceutical products, metal products, machinery, food, and rubber where they dominated (75-94 percent of workforce). In textile, they came close to one half ( 48 percent), followed by the giant Japanese concerns (39 percent) and the British mills (12 percent). On average, Chinese companies employed about one half of the workers in all other sectors, with various degrees of distribution among the other nationalities. Yet they were totally absent from public utilities, monopolized by British and American firms, and petroleum industry.

The spatial pattern was one of acquisition of large tracks of land in the more remote districts for the large premises required by integrated mills, especially cotton. This pattern dominated in the Eastern and Western districts along the rivers. The choice of location was also dictated by other considerations such as access to water for transportation (wharf facilities) and disposal of effluent. Thus cotton mills were concentrated exclusively in Yantszepoo and Yulin (East), Gordon, Pootoo (West), and ESRA. The silk industry, however, was widely distributed within the 'industrial ribbon' that lined the two rivers. Metal products, metallurgy, and machinery found their home in various districts, though with a higher concentration in Kashing, Yulin, and Wayside, a sign perhaps of a linkage effect with the textile industry. Printing and paper workshops were scattered all over the city, yet with the Northern district as a major base, followed by the more central district wards and Yulin (mostly for larger paper mills). If the occupation of the Eastern district could be construed as a form of industrial suburbanization, industries failed to induce urban development until after the war. The industrialized sectors of the Western district, conversely, were too close to the urban core to be regarded as suburban.

The Shanghai pattern remained mostly one of substantial industrialization in the core districts of the city - mostly smallsize workshops - which would actually get reinforced in the postwar period, and concentration of large factories in two small patches of land in the immediate vicinity of urbanized districts. The lingering war threat throughout the 1930s and two actual wars may have stifled the sort of development that drove factories to the outskirts in Montreal, Pittsburgh or Chicago. The facilities offered by rivers up- or downstream or by an expanding railway failed to attract entrepreneurs to move far away from the protection of the foreign settlements. The urban expansion of the city was virtually stopped during the war years, limiting the pressure on land, while the destroyed districts (Zhabei, parts of Nanshi) actually offered a kind of land reserve in previously urbanized districts. This particular political configuration combined to the effects of war go a long way to explain the contained nature of industries in Shanghai. ${ }^{19}$

\footnotetext{
19 See R.D. Lewis, Restructuring and the formation of an industrial district in Montreal's East End, 1850-1914, Journal of Historical Geography 20 (1994) 143-157; E.K. Muller, Industrial suburbs and the growth of metropolitan Pittsburgh, 1870-1920, Journal of Historical Geography 27 (2001) 58-73; R.D. Lewis, Chicago Made: Factory Networks in the Industrial Metropolis, Chicago, 2008.
} 
1940

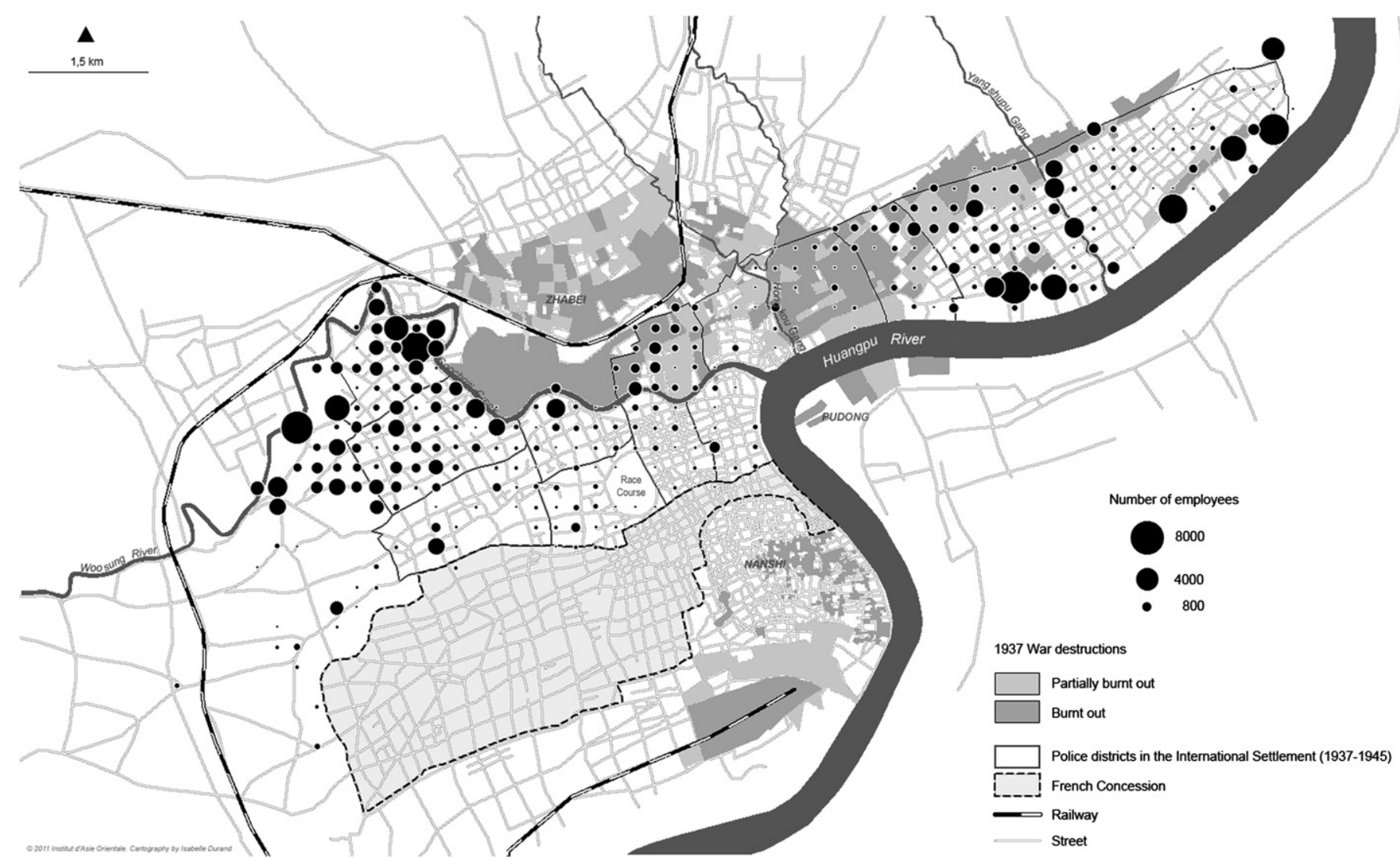

Fig. 3c. Factories and workforce, 1940.

\section{The impact of war on industries}

The Sino-Japanese hostilities in August-November 1937 brought all industries in Shanghai to a halt, either because of direct fighting in these areas or because of a near stoppage of all rail and sea transportation until the front line moved away from the city in November. In the intervening period until the authorities carried out the next industrial survey, Shanghai partly healed its wounds Zhabei never returned to its pre-war state - and industrial plants and workshops in the International Settlement resumed production when their premises had been preserved or only partly damaged. The major change, however, was a pattern of migration of industrial establishments all through the post-conflict years. At the local level, Shanghai exhibited patterns similar to that of Austria at the national level. ${ }^{20}$

Altogether there remained 835 industrial concerns with more than 10 workers in the International Settlement in 1938. The workforce dropped to 140,578 workers. The vast majority of these establishments remained Chinese-run (79\%), but the loss was manifest. Whereas foreign firms emerged from the war almost unscathed (or had quickly made up for damages) - in absolute number, they even increased slightly from 174 to 179 - the Chinese lost 481 plants. Chinese-run companies represented only 35 per cent of the workforce. The next big players were the Japanese ( 8 percent of companies and 42 percent of the workforce), the
British ( 7 percent and 18 percent) and the American (4 percent and 5 percent) companies. Altogether, the nationals from these three countries employed almost two thirds of the industrial workforce in a limited number of very large industrial concerns. Chinese industrialists dominated in a much smaller range of sectors: metal products, metallurgy, and rubber. In all the other sectors, their share had taken a solid dip, especially in textile (29 percent), tobacco (49 percent), and printing (70 percent). In the textile industry, the major toll was taken on the numerous silk workshops that populated the northern district.

Beyond numbers, however, the most striking change in the 1938 industrial landscape was the redistribution of plants in the urban space. This redistribution resulted from a combination of several factors. As most people evacuated from Zhabei before fighting started, small workshops with limited inventory must have moved into the safe haven of the International Settlement. In other words, these were 'new' companies that did not previously exist in the settlement. Unfortunately, there is no way to assess what was the share of these 'new' companies in the overall population of new industries. Another group of plants must have moved out of the more exposed or destroyed areas north of Soochow Creek within the International Settlement and set up shop again in other parts of the settlement. Finally, we know that industrial companies previously established in the towns and cities in a wide radius around Shanghai moved their machines into premises in the city, in the International

\footnotetext{
${ }^{20}$ D. Walker, Industrial location in turbulent times: Austria through Anschluss and occupation, Journal of Historical Geography 12 (1986) $182-195$.
} 
Table 1

War destruction and its impact on industries

\begin{tabular}{|c|c|c|c|c|}
\hline \multirow[t]{2}{*}{1937 War destructions } & \multicolumn{2}{|l|}{ In operation in 1938} & \multicolumn{2}{|l|}{ Closed between 1936 and 1938} \\
\hline & Number of industrial concerns & $\%$ & Number of industrial concerns & $\%$ \\
\hline Burnt-out area & 53 & 16.5 & 269 & $\overline{83.5}$ \\
\hline Partially burnt-out area & 39 & 16.1 & 203 & 83.9 \\
\hline Closed to affected zone & 39 & 25 & 117 & 75 \\
\hline Probably disturbed zone & 39 & 26.4 & 109 & 73.6 \\
\hline Out of affected zone & 39 & 22.3 & 136 & 77.7 \\
\hline
\end{tabular}

Settlement, as a way to protect their assets as war expanded in the lower Yangzi area. The industrial landscape in 1938 was quite strikingly different, even if some permanent features remained.

The first impact of war was the near complete erasure of industries in the areas affected directly by bombing and fires (Fig. 2). The wanton destruction of buildings made it impossible to resume production until new constructions and infrastructures were in place. Yet the disappearance of industries affected a much larger area than the totally burnt-out or partially burn-out blocks. Even when a block remained untouched, it could hardly provide a favorable site as all around only rubble remained. My analysis is based on the combined reading and analysis of a 1937 map and Japanese military aerial photograph that we georectified and introduced into our GIS. Using buffers to assess the density of plants in 1938 by comparison with the state of destruction, it made clear that the 1937 hostilities had a long-lasting impact, even if this area was not involved directly into the fighting (see Table 1 ). The three police wards of Hongkew, Kashing, and Wayside were by and large devoid of industries in 1938. The least affected were the large mills along the riverbank, which explains in part the limited drop of the workforce in textile. Yet the Eastern district garnered only $40 \%$ of all industrial jobs against 53\% before the war. West Hongkew, though badly beaten, offered a glimpse of initial recovery. The loss was also real in the Central district, which resulted from the stoppage of the local economy. This was a clear collateral damage. Finally, the major change was the emergence of the Western district as an alternative site for new industries or the concentration of industries previously located in the ESRA.

The creation of factories or their migration into the International Settlement went unabated the following year (Fig. 3). In August 1939, the SMP registered a new record of 1,696 factories with 209,680 workers. This was a 50 percent increase since 1936 and a 103 percent increase over the previous year. While the workforce continued to grow, however, the average number of employees decreased to 124, confirming the trend toward small industrial ventures seeking a safe haven in the settlement. By 1940, Shanghai

\section{Closed 1936-1938}

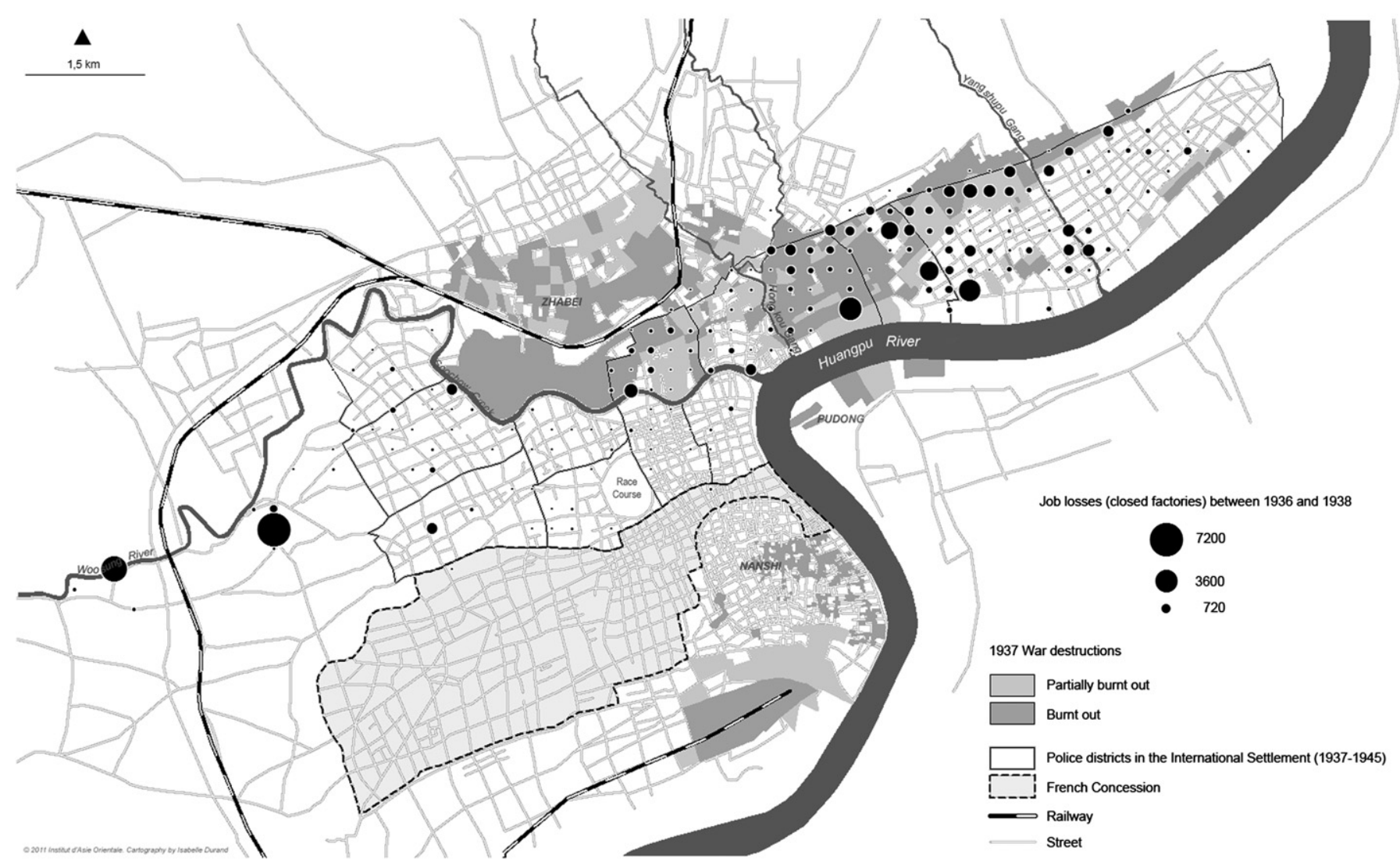

Fig. 4a. Factory closures, 1936-8 (grid-based). 
New factories 1939

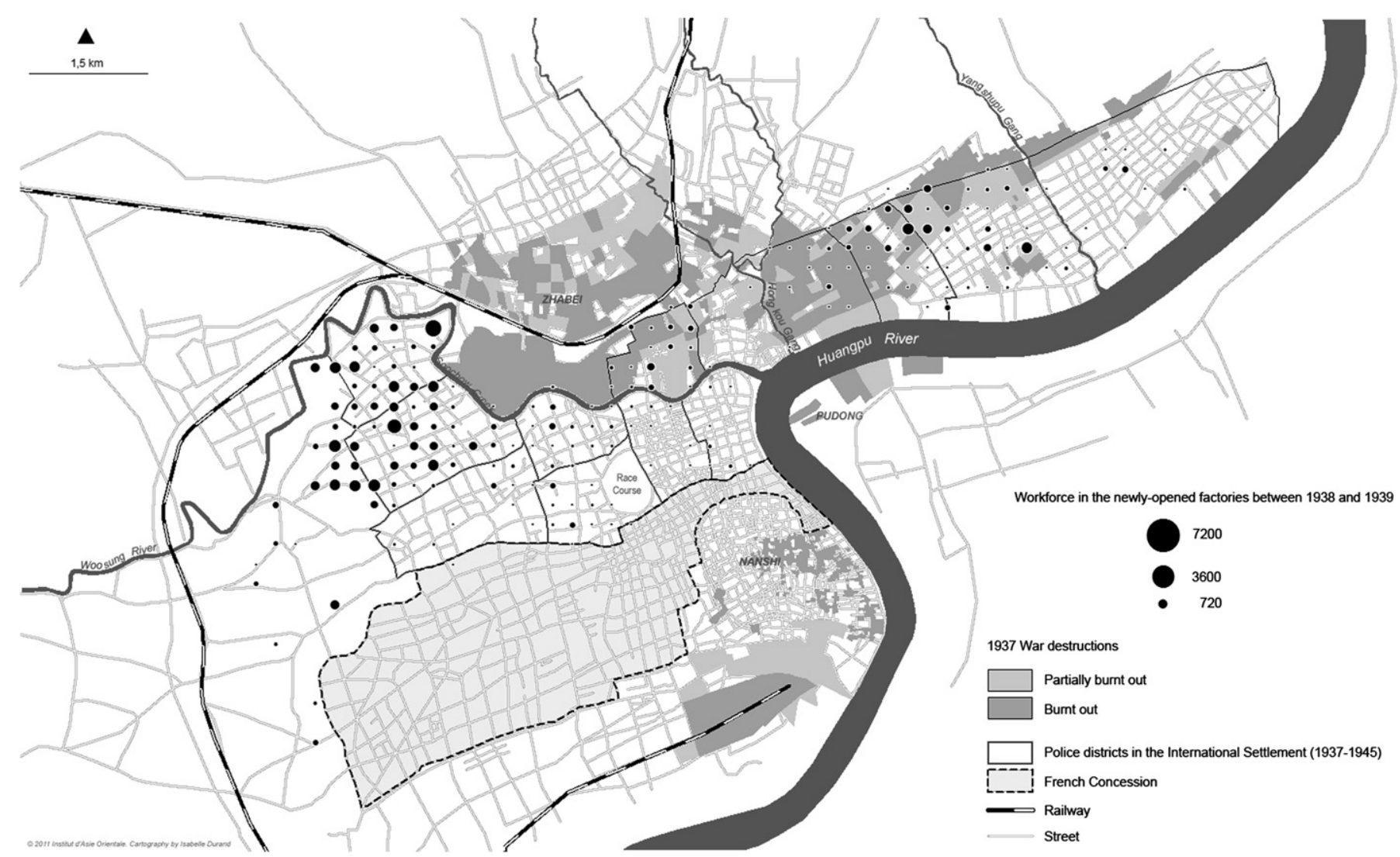

Fig. 4b. New factories, 1939 (grid-based).

industries had, with very few exceptions, not only recovered, but even surpassed pre-war levels. The factory population stood at 1,895 with a workforce of 226,657 and a continuing smaller average plant size (120 workers). The job market was clearly pulled ahead by the textile industry, with 147,117 jobs (65 percent). Chinese industrialists regained a stronger position, with 42 percent of the workforce in 1940. The British remained at the same level as in 1938. Only the Japanese lost out in relative terms ( 32 percent), but the size of their workforce increased substantially from 58,902 in 1938 to 72,998 in 1940 . They were definitely among the major beneficiaries of the post-conflict recovery and expansion.

With this new surge of industrialization on its territory, the International Settlement underwent another reconfiguration of the distribution of factories. The major trend between 1938 and 1939-1940 was a migration westward. Yet the combination of relatively untouched large integrated mills and a constellation of responsive small and middle-sized factories able to come back to life or to be created from scratch to meet the needs of the market led to a markedly quick but spatially differentiated recovery. In 1939, there was a serious recovery in the Eastern district, mostly in the more remote police wards (Yulin, Yangtszepoo) and along the eastern limit of Wayside. 1940 saw further progress of this pattern, but in share of industrial jobs the Eastern district remained at the same level (40 percent). Kashing, however, remained an industrial desert up to 1940 , probably due to the heavy material destruction of buildings.
West Hongkew confirmed its role as a core area for small and middle-size factories. If printing never resumed its erstwhile central position, this was compensated by a rise in workshops for textile, tobacco, and metal products. By 1940, its industrial structure had surpassed that of the pre-war period. In a way, it offered an ideal location, nearby the river connecting to the factories of the Western district, right across from the Central districts (potential market) and protected from Japanese encroachment, as was the case in the occupied districts (Zhabei, Nanshi). The most radical transformation was that of the Western district with a complete colonization of the area, especially Pootoo and Gordon districts, by industrial ventures. The two other districts right behind Central district, Sinza and Chengtu, also received a sustained influx of factories. Finally, even the more residential district of Bubbling Well were sparingly dotted with plants, causing Western residents to complain. ${ }^{21}$

Not all industrial sectors behaved in the same way. The spatial pattern of relocation was constrained by the nature and size of the factories. It also depended on the availability of machinery on the market, either to start afresh after war destruction or to launch a new company. Small and middle-size plants could more easily pack their inventory and move to a new and safer location as this happened throughout the International Settlement. The silk industry, hardly present in the settlement in 1936, settled en masse in the Western districts. The cotton industry, however, was made up of fairly large-scale factories with a huge inventory of

\footnotetext{
21 'Memorandum on conditions in the Western extra-settlement area,' 30 May 1938, SMA File U1-16-2108; The China Press, 19 March 1938, 2 April 1938; North China Daily News, 21 March 1938, 31 March 1938, 1 April 1938.
} 


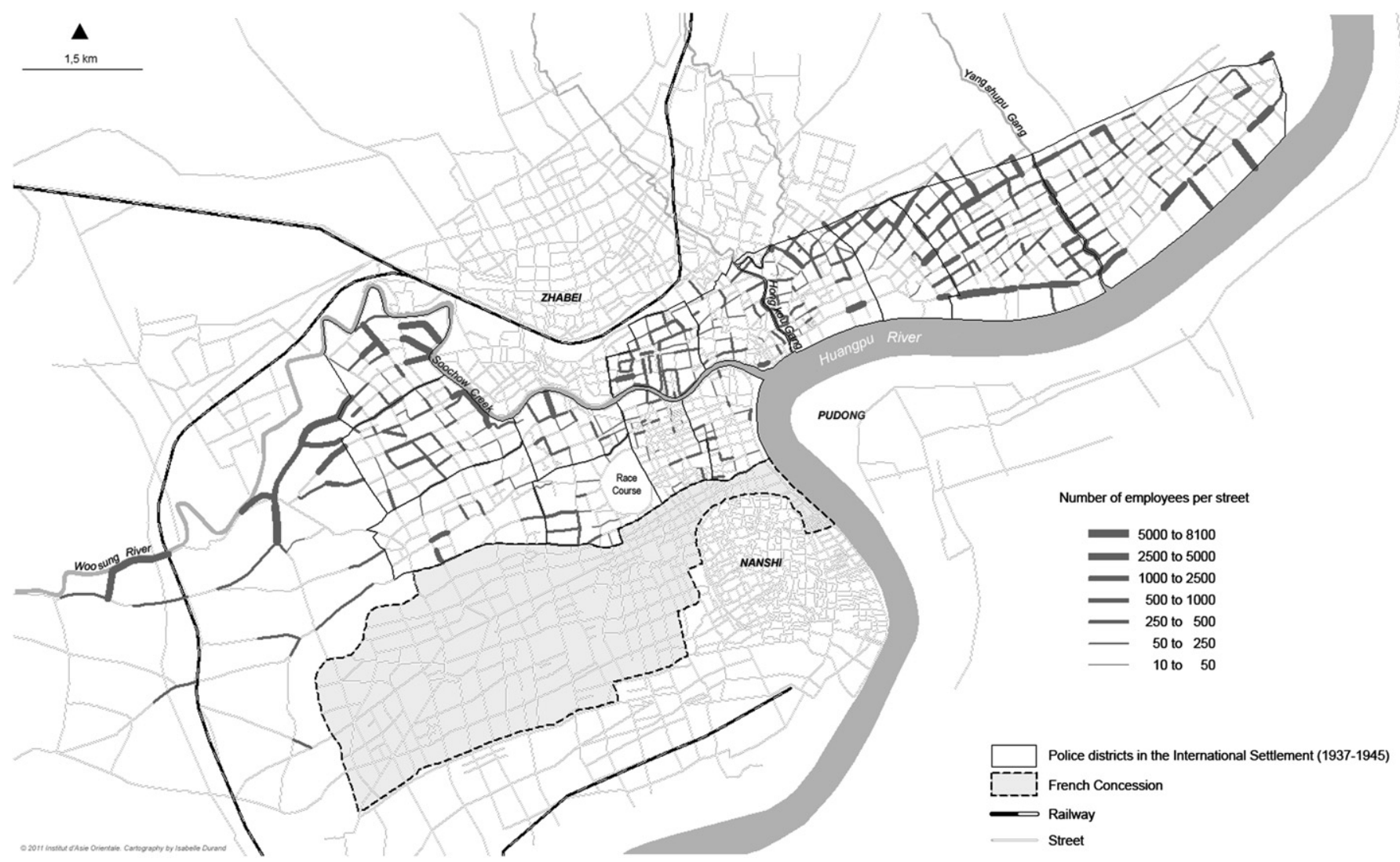

Fig. 5a. Industrial streets in 1936

equipment. They usually required very large premises. In case of an emergency like a military conflict, factory managers could only hope to be spared from bombing and destruction, as they could not remove their plants from the battlefield (Fig. 4). Actually, aside from Shanghai proper, cotton mills in interior cities like Wuxi, moved their machinery to Shanghai before war affected them. This could explain why and how new cotton mills emerged in the International Settlement as early as $1938 .^{22}$ By and large, the existing cotton mills in 1936 remained where they were. Pootoo and above all Gordon became the new base for Shanghai's textile industry, from 44 in 1936-180 factories in 1940.

Thus the major trend between 1938 and 1939/1940 was a migration westward. The whole Western area became the new center of gravity of industrial production in the city. Located in Yulin and Yangtszepoo at the periphery of the International Settlement, these districts still had a lot of vacant land on which industrial firms could easily set up shop. Pootoo, previously a major spot for textile industries - the famous Japanese company Naigai Watta had half a dozen mills in this area - presented a major advantage as it bordered Soochow Creek. While the migration of factories from the Eastern districts to the Central and Western districts can account for the large number of plants that established their seat there, there still remains a substantial discrepancy with the total number of plants that settled in Western Shanghai. The surge in numbers can only be explained by factories from the Chinese districts or regions that relocated for safety reasons and resumed production after a temporary setback as well as by the establishment of new companies. The vertiginous pace of industrialization in the West had a very strong impact at another level, that of the very rapid growth in the size of the population and the need for accommodation.

The profile of the textile industry underwent considerable change. Due to the size of their premises and inventory, the large integrated cotton mills mostly remained where they were. Actually, fighting mostly spared these factories. Between 1936 and 1938, they lost only 2300 -odd jobs, which were more than compensated in the following two years $(+47,000)$. Yet there was a relative displacement and concentration in the Western district. The new companies that emerged or moved in favored the two large police wards of Pootoo and Gordon. The spatial rearrangement among textile plants was foremost visible in the silk industry. The silk industry relied on a huge number of small plants and workshops. There was a total of 466 silk weaving plants and 44 silk reeling filatures in pre-war Shanghai. Most were located in Zhabei, the area contiguous to the International Settlement and in the Northern and Eastern districts of the International Settlement. By 1940, there were 308 factories in the sole International Settlement, with a workforce of 19,137 compared to 8,323 in 1936 and 5,608 in 1938 . While plants reoccupied the easternmost sector of the Eastern district, they massively resettled in the Western district that turned out to become Shanghai's premier silk producing district. There were 8,392 silk workers in the Western district and 3,040 in the 


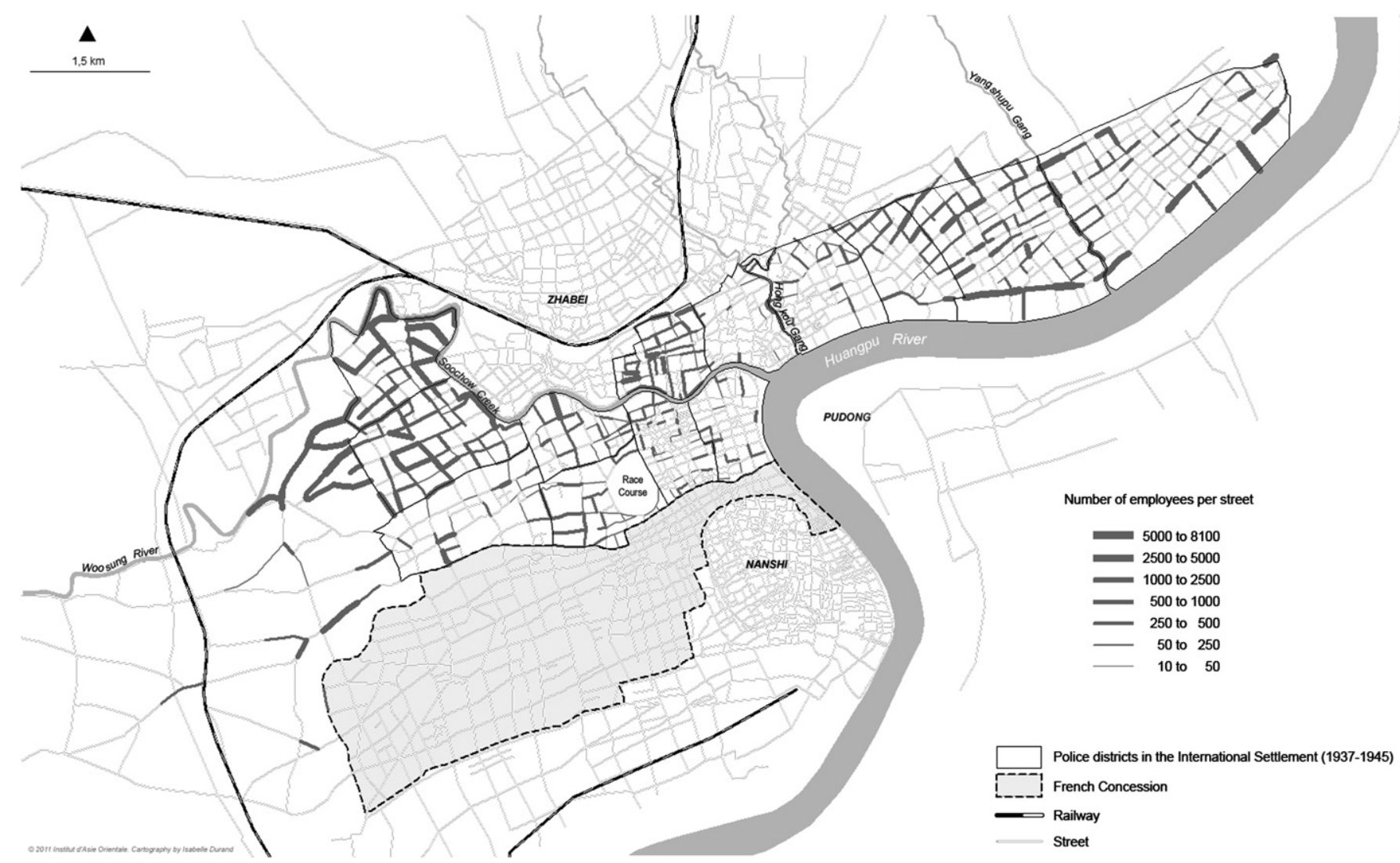

Fig. 5b. Industrial streets in 1940.

ESRA, representing together 60 percent of the workforce in this sector.

Metal products - this included a wide range of products - were quite present in the International Settlement before the war. There were basically two main concentrations: Kashing and West Hongkew districts. The sector was made up of a limited number of small to middle-sized plants. Machine manufacturing constituted a related sector, as it required parts and other items from the metal industry. In terms of structure as well, it was very similar to metal products, though with a few larger plants. The transformation of both sectors under the impact of war followed the same pattern of virtual disappearance from the Eastern and Northern districts in 1938, followed by a partial reconstitution in the Eastern district, a substantial splatter of workshops in the Central district, and above all an undeniable concentration in the two most industrialized Western police wards, Pootoo and Gordon.

The last sectors I want to examine are printing and paper processing. Both obviously had a structural relationship. There was a solid congregation on a square formed by the two northern police ward and the two central police wards in 1936, especially for printing. The size of most plants made it easy to settle in densely urban areas. The larger plants, in fact, were to be found in the Eastern district, especially Yulin. The war had a devastating effect. Only those located in the central district remained somehow immune to the consequences of fighting. In 1938, one can see the same distribution, but only south of Soochow Creek. North of the river war created a virtual desert, except in West Hongkew where a splatter of companies reemerged. Throughout 1939 and 1940, both sectors underwent a partial recovery, with printing remaining well under its pre-war level. In 1940, its total workforce still fell short of its original number by 28 percent, even if the number of presses had recovered from its 1938 collapse (from 143 to 204). Geographically, there was a near reversal between the Northern district (101 down to 41 plants) and the Western districts (51 up to 92 plants). Most printing and paper processing facilities elected their final destination in the Western district, even if many also colonized the more central police wards. We can observe the same pattern at work to various degrees in chemical industry, electrical equipment, tobacco industry, food industry, and rubber industry.

There is tangible evidence of the redistribution of industrial factories and workshops within Shanghai, with a clear trend toward a migration from Chinese-administered territory into the International Settlement. As such, this phenomenon was not surprising. After the occupation of the Chinese municipality by Japanese troops, the foreign settlements offered the best degree of protection and safety from pressure or abuse either by the Japanese armies or by the early collaborationist Dadao government. There was ample evidence of confiscation or occupation of plants by the Japanese army in the Chinese municipality, even two years after the end of the conflict. ${ }^{23}$ What is more difficult to assess if how this process developed. My major hypothesis is that this was not just the result of an intra-city migration. Of course, the factories and 


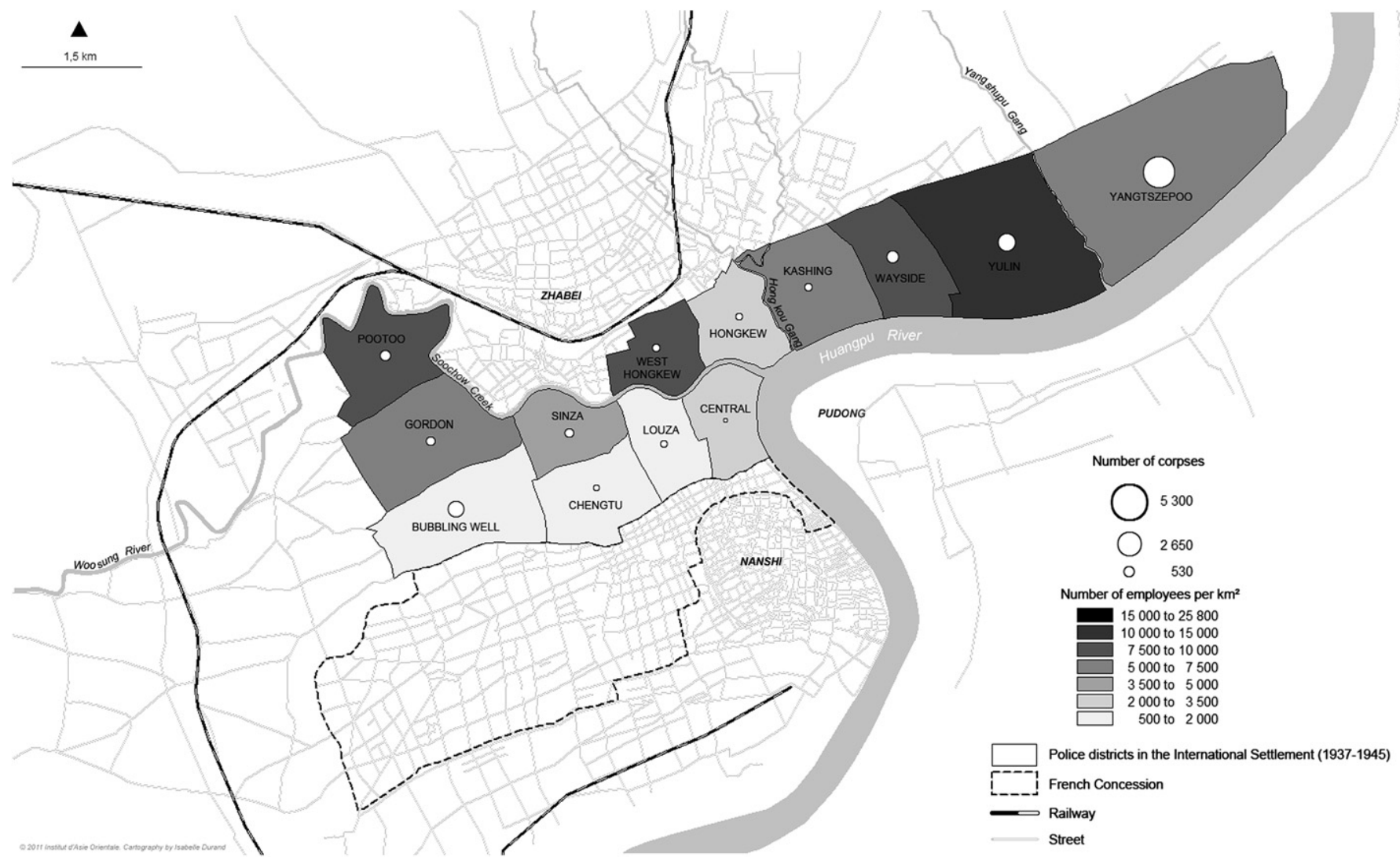

Fig. 6a. Distribution of exposed corpses and coffins in 1936.

workshops previously located in Zhabei and close parts of the Chinese municipality moved physically into the International Settlement, but even within the settlement there was a high level of mobility until 1940.

The sense of crisis and emergency that started with the Japanese invasion in North China in July 1937 and deepened with local incidents in Shanghai must have caused a serious alarm not just among residents, but also among plant owners and managers. The violent 1932 conflict was still very present in the memories. ${ }^{24}$ If residents started to flee en masse, there is good reason to imagine that some plant or workshop owners sought to move their tools and machines to a safer place. This could not be a movement as massive as the population of residents as machines represented substantial heavy weight. Yet given the astuteness of residents by way of means of transportation to escape from Zhabei, machines could have been scrapped down and moved on trucks and even handcarts. Yet, the migration was not limited to the factories located in Shanghai proper, but also from the neighboring cities and towns. The managers of these plants assumed that moving into Shanghai meant locating only in the International Settlement, the only place that offered protection, no restriction on use on land use, and relatively large tracks of vacant land. This was especially true of the family conglomerates in textile or flour industry who owned factories in various parts of the city or the region. The long months of battle first in North China, then around Shanghai left them time to prepare for an organized move to the safe haven of the foreign settlements. As military operations shifted to the West and eventually winded down, these groups took advantage of family networks to operate across lines in occupied and Chinese-

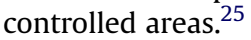

The choice of the Eastern district was not immediate. War had come close to the large textile mills, while entire police wards were fully destroyed. Nevertheless, the district undoubtedly offered the largest stock of vacant land at affordable prices. Once the threat of war was plainly removed, entrepreneurs moved back in, in part probably because of the presence of the large textile mills to which they could offer their services and products. Yet, history had taught Chinese industrialists a hard lesson. If the Yangshupu area offered a relative degree of protection, it was far removed from the 'central districts' of the International Settlement. As little space was available in the core areas of the settlement, the natural choice for Chinese plants was to move into the spacious Western districts along Soochow Creek, especially for textile firms that required water, and into the previously residential areas west of the Racecourse. The general trend was quite clearly a move based on a rational choice for security. Land prices remained low in these sectors of the settlement. There was therefore no serious obstacle to resettlement or opening up a new factory. It is quite interesting to note that due to the stringent limits imposed on industrial establishments in the French Concession, the International Settlement

\footnotetext{
24 D.A. Jordan, The Northern Expedition: China's National Revolution of 1926-1928, Honolulu, 1974, 47.

25 Coble, Chinese Capitalists in Japan's New Order (note 3), 111; see also F. Wakeman, Shanghai smuggling in: Henriot and Yeh, In the Shadow of the Rising Sun, 116-153.
} 


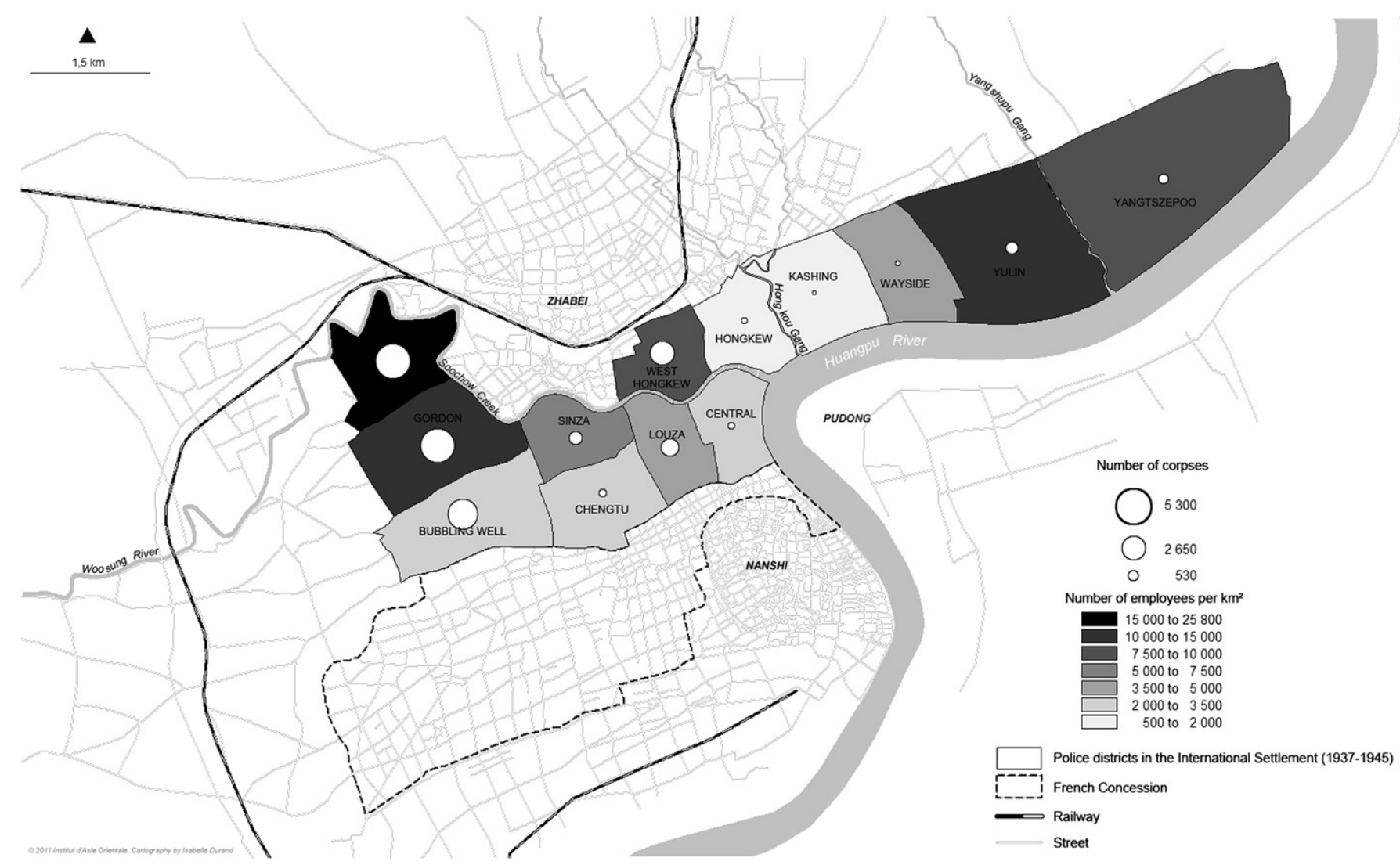

Fig. 6b. Distribution of exposed corpses and coffins in 1939.

unwillingly became the receptacle of security-longing Chinese entrepreneurs. ${ }^{26}$ As in other matters - civilian population, coffins the International Settlement was the refuge area par excellence, to the great concern of its authorities and the foreign population. ${ }^{27}$ The general pattern, therefore, was more one of concentration of industries near the urban core than one of deployment in suburban areas due to the insecurity resulting from the Japanese occupation.

The establishment of large numbers of industrial factories changed the morphology of the city in many ways. On the one hand, previously vacant land and roads turned into busy areas. Workers occupied the space in different ways. The first aspect was commuting. Even if most settled in close-by areas, some streets were 'colonized' by the regular flow of works on their way to or from work. There is no way to grasp fully how much change industrial colonization generated. Yet the sheer numbers of workers who labored in both the large mills and small factories constituted a concrete physical presence at work or on the streets. Fig. 5 shows the changing geography of 'industrial streets'. They clearly reflect the process of relocation of factories over the territory of the International Settlement. We still have no clear idea of the patterns of transportation and human flows that overtook the streets at certain hours, although this could be done for large mills with data on factory shifts. Similarly, we hardly have a clear idea about how services organized around the presence and movement of the working population, especially peddlers, restaurants, markets, etc. to serve the needs of this population. The 1939 commercial atlas offers a detailed snapshot at the block level for permanent establishments. We know, however, that roving peddlers addressed the needs of the worker population. Again, this is an elusive reality.

Another consequence of the relocation of industrial firms was the need for worker housing. Not much has been written about workers' accommodation in Shanghai's industrial districts. ${ }^{28}$ What happened when a large influx of workers took over a neighborhood? What happened when they left and moved to an entirely new sector? What kind of housing could they afford? As factories opened in the Yangshupu area in 1938, massive numbers of working families moved in. When these factories moved west, the workers followed their employers. Fig. 3 makes clear the displacement of industrial jobs to the Western district. These areas were not prepared to receive a large influx of population. There were few decent houses to accommodate workers, even for those who could afford to pay a rent. Actually, the housing problem of workers had become early a serious issue that the Shanghai Municipal Council failed to address squarely.

Basically, workers were left to themselves and reproduced a model of housing that was common in the countryside. Mostly, as

\footnotetext{
${ }^{26}$ While there were 270 dyeing and weaving mills in Shanghai before the war - many were destroyed during the conflict - 240 reopened in the International Settlement in the early part of 1939. China Weekly Review, 16 November 1940, 361.

27 C. Henriot, Shanghai and the experience of war: the fate of refugees, European Journal of East Asian Studies 5 (2006) 217-248; Scythe and Sojourning in Wartime Shanghai, Karunungan - A Journal of Philosophy 27 (2007) 117-148.

${ }^{28}$ See H. Lu, Creating urban outcasts: shantytowns in Shanghai, 1920-1950, Journal of Urban History 21 (1995) 563-596.
} 
we know from the SMC surveys in 1926 and 1931, workers built their own shelters with straw matting, bamboo, mud, tinfoil cans, etc. Such 'hutments' became a major object of concern by the SMC that tried to get rid of them. ${ }^{29}$ It was a hopeless task, especially during the war. The major difference with rural housing, however, was the high density of such dwellings, with hardly any sanitary amenities, which actually created wholesale slums with thousands of residents. Fires - a characteristic of such housing all along became more frequent and more destructive, leaving thousands of families without a roof in a matter of a few hours. Like Sisyphus, workers would unrelentingly rebuild their mud sheds on the same location. In the Chinese-administered districts north of Soochow Creek, the same phenomenon led to the full squatterization of Zhabei. One of the major side-effects and legacies of war, therefore, was the 'rise of the slums' in the city, a phenomenon that accelerated even more quickly in the postwar/civil war period.

One of the most tragic dimensions of pre-war urban life was the issue of mortality, especially the high mortality rates among the less privileged segments of the population. In a recent study, I have examined the issue of exposed corpses and coffins in the city. ${ }^{30}$ The general pattern was one of high mortality of young children (85\% on average, with more adults during the war years). The data I collected during the war years had established that whereas the highest concentration was to be found in Yangtszepoo and Yulin before the war, the pattern changed radically with Pootoo and Gordon becoming the divisions with the highest number of exposed corpses. My original interpretation was based on a general demographic perspective: as population decreased in the Yangshupu area, so did the number of exposed corpses. Yet the study of industrial migration points to a much more focused explanation: those who died in high numbers were the children of workers, not those of the poor refugees or impoverished slum dwellers; workers who had jobs and wages, with less than adequate housing for sure, but on the whole a fairly stable population. Yet this population saw its children die massively of benign, but untreated diseases, undernourishment and bad housing conditions. The more workers the city harbored, the more exposed corpses of children there were. This issue did not come to an end until the early 1950s. Fig. 6 points to an interesting if puzzling phenomenon. The number of exposed corpses increased massively in the Western districts along with population increase. In the Eastern district, the pattern of a high level of population did not match a correspondingly high number of exposed corpses. I have no ready answer, except perhaps through housing conditions. ${ }^{31}$ Straw huts became much less concentrated in the Eastern district compared to the Western area where very large-scale and unsanitary 'hutment' villages developed. ${ }^{32}$

\section{Concluding remarks}

This study has established a pattern of high spatial mobility of industrial concerns in Shanghai in the early years of the war. Shanghai industries, especially Chinese-run factories, were not just acutely reactive to the new environment created by the war - both in terms of loss and opportunity - factory and workshop owners relocated or established their premises where they felt most secure, in the International Settlement. Whereas the French Concession maintained a sort of 'anti-factory' stand, the Shanghai Municipal
Council was known for its laissez-faire attitude and even policy that left its territory open to industrial development. The SMC actually admitted internally its lack of legal zoning power and only exercised enough pressure to avoid having large plants in the Central district. $^{33}$ The war caused a drastic redistribution of industrial concerns and workforce in the city. Chinese-administered areas 'de-industrialized', while the International Settlement 'overindustrialized'. Industry came to be far more concentrated in a limited territory, even in very specific sectors like the Western districts. The shrinking size of industrial territory paralleled an unprecedented increase in factories. This process of reconcentration reflected the structure of industries - myriads of mobile smallscale workshops - as much as the spatial arrangement resulting from a unique political and military configuration. War set a pattern that differed from the experience of earlier industrial development in European or American cities where the requirements of modern industry somehow pushed factories away from city centers.

The redistribution of industrial concerns in the International Settlement also generated new patterns of use of space as thousands of workers literally invaded the newly industrialized streets. These internal moves forced the workers to adapt and find ways to settle nearby their workplace. As no authority cared for their housing, they followed well-trodden paths in constructing cheap huts with all kinds of discarded materials. These slum-like hutments created fairly precarious living conditions for which children paid a very high price in mortality rate. While Shanghai regained its pre-war level as an industrial engine, this was achieved through a densification of industries in the more central part of the city, with the outlying districts - Chinese-administered areas turned into massive slums. The decline of industries after the Japanese occupation of the International Settlement in December 1941, following Pearl Harbor, had at least one beneficial effect: it relieved the pressure on land for industrial premises and worker housing. Yet, it also left a legacy of seriously unbalanced development and compounded housing problems. The immediate postwar period saw a new surge in industrial development that the municipal government could only monitor, but not influence. It provided the basis on which the People's government carried out its own version of industrialization at all costs, under new collective ownership, but with the same deleterious effects on urban space.

\section{Acknowledgments}

This paper is part of a research project - Cities in Turmoil generously funded by the Chiang Ching-kuo Foundation for International Scholarly Exchange (ROC). The author also wishes to acknowledge the contribution of Isabelle Durand, GIS specialist, in processing and analyzing spatial and statistical data for this paper. Finally, I wish to express my gratitude to the anonymous reviewers for their constructive comments.

\section{Supplementary material}

Supplementary material associated with this article (comprising 15 maps showing the distribution of factories, by industrial sector, in 1936, 1938 and 1940) can be found in online version at doi:10. 1016/j.jhg.2011.12.001.

\footnotetext{
29 On SMC policy, see Files U1-3-1370 and U1-3-1371, SMA.

30 C. Henriot, 'Invisible Deaths, Silent Deaths'. 'Bodies Without Masters' in Republican Shanghai, Journal of Social History 43 (2009) $408-437$.

31 I collected data over the 2010 summer and plan to map out 'hutments' in the Western district.

32 Minutes, Health Committee, 20 May 1938, File U1-16-2195, SMA.

33 'Memorandum,' 30 May 1938, File U1-16-2108 (1938-1939), SMA.
} 